\title{
O método clínico - 3
}

Manoel Tosta Berlinck

Durante o século XIX ocorreram dois eventos na medicina que tiveram ampla repercussão sobre a psiquiatria e sobre o método clínico.

O primeiro foi a consolidação da anatomia, permitindo que a medicina passasse a ser regida pelo par conceitual normal-patológico determinado pela lesão de órgão. Como observa Estellita-Lins (2007) em "Visibilidade na clínica psicanalítica: epistemo-lógicas a partir do Princípio de Broussais", a medicina interna não deve ser entendida como algo que sempre existiu e que opera de modo consolidado, demarcado e normalizador.

Com o nascimento dessa clínica, a doença passa a habitar o espaço e a espessura do corpo (Foucault, 1977, p. 1413). Ela não provém mais de fora, pois doravante deve ser buscada em seu interior tomando irritações e inflamações como modelo (Canguilhem, 1978, p. 33-6). Este novo campo conceitual não podia ser pensado pela medicina nosográfica do século XVIII, contudo tornou-se uma poderosa alavanca para as ciências médicas nos séculos XIX e XX.

$O$ fundamento da medicina interna situa-se na lesão anátomo-patológica, que referenda um privilégio do visível onde 
a experimentação científica poderá ancorar-se. Inicialmente, a medicina experimental tratava exclusivamente de alterações morfológicas ou estruturais, mas com o decorrer do tempo a lógica da lesão passou a compreender perfurações funcionais ou moleculares que podem ser sutis ou efêmeras.

A clínica ganha então seu sentido pleno, de inclinar-se sobre o enfermo para auscultar, tocar, percutir, cheirar, palpar, pressionar, observar, olhar, mas sobretudo para traduzir estes signos, verdadeira linguagem da natureza, em recortes visíveis desenhados no corpo que adoece. O exame físico que cada clínico realiza em sua prática cotidiana consiste em um processo de prospecção que pratica uma investigação sensorial de fenômenos específicos. Seria pertinente perguntar sobre o estatuto de escrita ou leitura praticada pela semiologia médica, que parece admitir uma hermenêutica onde o texto original encontra-se redigido em linguagem anátomo-patológica. Examinar um paciente implica passar da anamnese ao exame físico e aos exames complementares, mantendo a patologia indutiva e dedutivamente assentada no horizonte. Embora doença, patologia e anormalidade não possuam sempre o mesmo sentido, como demonstra Canguilhem, qualquer patologia é capaz de informar positivamente sobre uma condição anormal enquanto particularidade do vivente doente.

A visibilidade representa também um modo peculiar de síntese. Verifica-se, desse modo, que o regime do visível se opõe doravante àquilo que permanece invisível. O que pode ser visto depende de um saber correlato. Aqui se reconhece, com alguma facilidade, a tradicional prevalência do sentido da visão na estrutura sintética do conhecimento que vigora desde a antigüidade grega até o século XVIII. O conjunto dos sinais colhidos pelos órgãos dos sentidos, onde se deve incluir a visão de modo privilegiado, fica subordinado ao campo da visibilidade da lesão que opera como princípio de organização.

Toda a positividade efetiva sobre a qual a medicina pôde constituir-se repousa neste privilégio do visível, que legitima seu caráter experimental. O espaço, enquanto espaço do corpo, reencontra sua vocação de imagem - esquematismo, imaginação e imaginário -, sendo exatamente em função desta incorporação que será possível falar em lesão de uma maneira multifacetada e definitiva.

Desde o nascimento da clínica descrito até aqui, voltou-se a suspeitar, de modo mais convicto que nunca, que o espírito - seja alma ou psique - deveria depender diretamente de um órgão: o cérebro. O próprio termo "doença nervosa" que caracterizava a clínica da doença mental na aurora do século XX indica a expectativa de uma localização patológica precisa e evidente. A medicina dos nervosos teve, contudo, enorme dificuldade em estender a lógica da lesão aos seus domínios. Como resultado dessa enorme dificuldade, ou seja, de um âmbito do patológico sine materiae, surge a psicopatologia como um discurso narrativo a 
respeito das doenças mentais, doenças sem lesão, apesar das insistentes tentativas médicas.

Os médicos que se dedicaram às doenças mentais, inicialmente denominados de alienistas por viverem em asilos e, mais tarde, de psiquiatras, constituem um caso particular da medicina clínica, que se afasta, cada vez mais, graças aos avanços da observação e da detecção de sinais anátomo-patológicos.

Aos alienistas, e posteriormente aos psiquiatras, restaram três possíveis explicações para as doenças sem lesão de órgão: 1) a indisciplina, que resultou no tratamento disciplinar e suas variantes (o tratamento moral, o magnetismo e a hipnose, a contenção); 2) a degenerescência ou degeneração e o ambiente cultural; 3) restou, também, o recurso da narrativa clínica, que acabou por se constituir numa rica psicopatologia.

Foucault tratou dessas questões em "O poder psiquiátrico" e em outros trechos de sua vasta obra.

A degenerescência ou degeneração possui uma curiosa trajetória, que tem início com Morel e Magnam, passa pelo racismo animal, avança no racismo humano que termina no nazismo e renasce, agora, com a genômica psiquiátrica.

Octavio Domont de Serpa Júnior (1998), em Mal-estar na natureza, examina com grande acuidade e profundidade a teoria da degenerescência e sua longa trajetória posterior, na medicina. Segundo esse autor, desde o princípio a teoria da degenerescência era compreendida por Morel como o avesso necessário da noção de progresso, entendido como a marcha contínua e necessária que leva da ignorância para o conhecimento, da barbárie para a civilização. E na medida em que era percebida como o correlato negativo da civilização, a degenerescência ocupou um lugar privilegiado no imaginário social da época. Discurso científico, portanto com sólidas aspirações de verdade, pretendia fornecer a compreensibilidade das transformações pelas quais passavam as cidades e suas crescentes populações de trabalhadores. Estes, que entregavam suas vidas às fábricas, minas e estradas de ferro, submetidos a regime de trabalho desumano, e que se acotovelavam em moradias de condições miseráveis e insalubres no coração das grandes metrópoles, eram percebidos como encarnando o próprio mal, manifestado no consumo excessivo de álcool, na violência e na criminalidade, na prostituição e na devassidão. Enfim, a degenerescência é o nicho que recebe todas as figuras do desvio, além do louco, o criminoso, a prostituta, o beberrão, o violento, o neurastênico, até chegar ao genial e desequilibrado artista criador.

Recentemente, certos psicanalistas introduziram "a contemporaneidade", palavra-ônibus que se multiplica em títulos de artigos e livros, numa evidente jogada mercadológica, para tratarem de uma "nova" degenerescência: o mal-estar na contemporaneidade. 
A versão "progressista" da degenerescência - a eugenia -, por sua vez, vai ser elaborada nos Estados Unidos e é magistralmente descrita por Edwin Black (2003) em A guerra contra os fracos. A eugenia e a campanha norte-americana para criar uma raça superior.

A eugenia é um vasto programa de esterilização de homens e mulheres considerados inadequados para viverem num mundo onde reina o progresso. Tratase, em última instância, de um vasto programa de eliminação dos considerados fracos para o mundo do progresso.

Em meio a esses procedimentos clínicos que visam a contenção, a disciplina e a esterilização dos loucos, a medicina do final do século XVIII e do século XIX elaborou um vasto painel narrativo sobre a loucura que muito contribui para a compreensão dessa produção humana. A esse longo e rico painel dá-se o nome de psicopatologia.

A psicopatologia clássica contribui, de forma decisiva, para aquilo que pode ser denominado de "a revolução freudiana". Mas isso só pode ser motivo de um outro texto.

\section{Referências}

BlACK, E. A guerra contra os fracos. A eugenia e a campanha norte-americana para criar uma raça superior. São Paulo: A Girafa, 2003.

CAnguilhem, G. The normal and the pathological. New York: Zone Books, 1991. . Escritos sobre a medicina. Trad. de Vera Avellar Ribeiro. Rio de Janeiro: Forense Universitária, 2005.

Estellita-Lins, C. E. Visibilidade na clínica psicanalítica: epistemo-lógicas a partir do Princípio de Broussais. Pulsional Revista de Psicanálise, ano XX, n. 189, p. 27-42, mar.2007

Foucault, M. O nascimento da clínica. Trad. de Roberto Machado. Rio de Janeiro: Forense Universitária, 1994.

. O poder psiquiátrico. Trad. de Eduardo Brandão. São Paulo: Martins Fontes, 2003.

SERPa JúnIOR, O. D. Mal-estar na natureza. Belo Horizonte: Te Corá, 1998. 